\title{
IDENTIFIKASI DAN ANALISIS INTANGIBLE VALUE ATAS BAGI HASIL TABUNGAN DI PERBANKAN SYARIAH \\ (Studi Kasus Penabung di PT Bank Pembiayaan Rakyat Syariah Muamalat Harkat Bengkulu)
}

\author{
Amir Mukadar \\ Universitas Muhammadiyah Bengkulu \\ Email : mirmukadar@yahoo.com
}

\begin{abstract}
ABSTRAK
Amir Mukadar ; Penelitian ini bersifat deskriptif, ekploratif dan implementatif, didesain dengan metode kualitatif dan kuantitatif, serta menggunakan data primer dan sekunder. Data primer berupa kuesioner, observasi lapangan, interview para pelaku dan survey responden. Sedangkan data sekunder didapatkan dari data yang sudah dipublikasikan dan telah menjadi domain untuk masyarakat umum. Jenis variabel bersifat explanatory research dengan beberapa bagian penjelasan yang bersifat deskriptif qualitatif. Beberapa bagian lainnya menggunakan perhitungan kuantitatif dan bersifat implementatif dengan analisis dan hipotesis secara empiris dilapangan. Berdasarkan penelitian diperoleh hasil Identifikasi dan Analisis Intangible Value atas Bagi Hasil Tabungan di PT Bank Pembiayaan Rakyat Syariah (BPRS) Muamalat Harkat Bengkulu pada elemen "kesesuaian aqidah" mempunyai pengaruh yang signifikan terhadap minat para penabung di BPRS dan mempunyai nilai yang paling tinggi, sementara pada elemen "kemamfaatan sosial" mempunyai pengaruh yang signifikan terhadap minat para penabung di BPRS, tetapi mempunyai nilai yang paling rendah. Diharapkan semua pihak yang terkait diantaranya pihak Manajemen BPRS, Otoritas Jasa Keuagan, Majelis Ulama Indonesia untuk lebih maksimal dalam mensosialisasikan tentang perbankkan syariah, segingga semakin baya asyarakat yang tertarik utuk embuka rekening tabungan di perbankan syariah khususnya di PT Bank Pebiayaan Rakyat Syariah (BPRS) Muamlat Harkat
\end{abstract}

\section{ABSTRACT}

Amir Mukadar ; This Research is descriptive, explorative, and implementative, which it's designed by qualitative and quantitative method. It also uses primary data - which consists of survey, field observation, and interviews - and secondary data - which consists of previous variable that has been issued before. Its variable is explanatory research with some part of it is descriptive qualitative.Another part of it is using qualitative calculation and implementative which empirically analysis and hypotesis in the field. This research showed that identification and intangible value analysis of profit sharing of the saving in PT. BPRS Muamalat Harkat Bengkulu has significant influence toward customer interest in element of kesesuaian aqidah, while in element of kemanfaatan sosial has same effect but with lower value. Ther author expected all things - BPRS managemet, Financial Authority, Moslem Clerc Council - to be better and have maximum effort for socializing sharia banking. It is expected that people have their interest to open their account in sharia bank, especially in PT. BPR Muamalat Harkat.

Keywords : Tahwidi String Relation (TRSR) Tabungan, Intangible Value for profit sharing

\section{LATAR BELAKANG}

Perkembangan perbankan syariah secara nasional dalam Kurun waktu lima tahun terakhir menunjukan perkembangan yang cukup pesat, baik pada Bank Umum Syariah (BUS), maupun BPR Syariah, perkembangan ini terlihat dari jumlah asset dan Jumlah dana pihak ke tiga (Giro, tabungan dan Deposito) yang berhasil dihimpun oleh Bank Syariah.

Asset perbankan syariah pada akhir tahun 2014mencapai Rp. 278,92 triliun. Pada posisi triwulan ke tiga tahun 2018 jumlah asset bank syariah mencapai Rp. 468,82. trilyun mengalami pertumbuhan sebesar Rp. 189,90 trilyun atau sebesar 68,09 \% (rata-rata pertumbuhan asset per tahun sebesar $17,02 \%$ ).

Pertumbuhan bank syariahpun terjadi di propinsi Bengkulu dimana jumlah asset dan dana pihak ke tiga mengalami pertumbuh

an selama empat tahun terakhir ini, Asset perbankan syariah di propinsi Bengkulu pada akhir tahun 2014 mencapai Rp. 1,03 trilyun. Pada posisi triwulan ke tiga tahun 2018jumlah asset bank syariah mencapai Rp. 1,57 trilyun mengalami pertumbuhan sebesar Rp. 539 milyar atau sebesar $52,28 . \%$ (rata-rata pertumbuhan asset per tahun sebesar 13,07. \%). 
Dalam hal Penghimpunan Dana Pihak Ketiga (DPK) perbankann syariah di propinsi Bengkulu pada akhir tahun 2014 mencapai Rp. 593 milyar. Pada posisi triwulan ke tiga tahun 2018 jumlah Dana Pihak ke tiga perbankan syariah mencapai Rp. 937 .milyar mengalami pertumbuhan sebesar Rp. 344 milyar atau sebesar 58,01\% (rata-rata pertumbuhan dana pihak ke tiga per tahun sebesar $14,50 \%$ )

Pertumbuhan perbankan syariah yang terjadi di propinsi Bengkulu baik dari sisi asset maupun dana pihak ketiga mencerminkan telah berjalannya fungi intermediasi perbankan syariah, dalam hal ini bank syariah sudah berhasil menghimpun dana dari masyarakat (dana pihak ke tiga) berupa simpanan yang artinya tingkat kepercayaan masyarakat Bengkulu untuk menyimpan dananya di perbankan syariah cukup tinggi, turutama bagi masyarakat yang betul-betul mempunyai tingkat emosional yang cukup tinggi ( loyalitas, kepedulian dan perhatian terhadap bank syariah).

Berdasarkan latar belakang tersebut maka penulis tertarik untuk membahas masalah :"Identifikasi dan analisis Intangible value atas bagi hasil tabungan di perbankan syariah (Studi kasus penabung di PT Bank Pembiayaan RakyatSyariah Muamalat Harkat Bengkulu)".

\section{LANDASAN TEORI \\ Bank Syariah}

Salah satu usaha untuk merealisasikan prinsip-prinsip ekonomi Islam dalam aktivitas masyarakat secara nyata adalah dengan mendirikan lembaga-lembaga keuangan yang beroperasi berdasarkan syariat Islam dari berbagai jenis lembaga keuangan perbankan merupakan sektor yang paling memberikan pengaruh yang besar dalam aktivitas perekonomian masyarakat modern (Sukri Iska, 2012).

Karakteristik sistem perbankan syariah yang beroperasi berdasarkan prinsip bagi hasil memberikan alternatif sistem perbankan yang saling menguntungkan bagi masyarakat dan bank, serta menonjolkan aspek keadilan dalam bertransaksi, investasi yang beretika, mengedepankan nilai-nilai kebersamaan dan persaudaraan dalam berproduksi, dan menghindari kegiatan spekulatif dalam bertransaksi keuangan. Dengan menyediakan beragam produk serta layanan jasa perbankan yang beragam dengan skema keuangan yang lebih bervariatif, perbankan syariah menjadi alternatif sistem perbankan yang kredibel dan dapat dinikmati oleh seluruh golongan masyarakat Indonesia tanpa terkecuali.

Secara tegas pengertian Bank diatur di dalam Pasal 1 ayat (2) Undang-undang Nomor 21 Tahun 2008 Tentang Perbankan Syariah. Di sana dijelaskan bahwa

"Bank adalah badan usaha yang menghimpun dana dari masyarakat dalam bentuk simpanan dan menyalurkannya kepada masyarakat dalam bentuk pembiayaan dan atau bentuk-bentuk lainnya dalam rangka meningkatkan taraf hidup orang banyak".

"Perbankan Syariah adalah segala sesuatu yang menyangkut tentang Bank Syariah dan Unit Usaha Syariah, mencakup kelembagaan, kegiatan usaha, serta cara dan proses dalam melaksanakan kegiatan usahanya (UU No. 21 tahun 2008)".

Pengertian lain dari Bank Syariah adalah Bank yang beroperasi dengan tidak bergantung pada bunga, dalan definisi lain Bnak syariah adalah lembaga perbankan yang selaras dengan istem, nilai dan etos Islam (Sukri Iska, 2012).

\section{Bank Pembiayaan Rakyat Syariah (BPRS)}

Terminologi Bank Pembiayaan Rakyat Syariah (BPRS) mulai digunakan beberapa tahun terakhir untuk menggantikan terminologi Bank Perkreditan Rakyat Syariah, dengan tanpa merubah esensi dan materi yang terkandung atas kata "Pembiayaan" dan "Perkreditan". Tentu saja ada falsafah dibalik itu, bahwa dalam kontek pemahaman kata "Perkreditan" mengandung unsur peminjaman dengan imbalan bunga, yang tidak sesuai dengan kaitan institusi berbasis syariah. Sedangkan kata "Pembiayaan" terkandung unsur kongsi atau kerjasama yang sesuai dengan bisnis secara Islami. Tak ada yang salah dengan falsafah tersebut diatas, walaupun realitas dilapangan belum tentu seperti yang diharapkan.

\section{Tabungan Syariah}

Bank Syariah mempunyai peranan sebagai lembaaga perantara (Intermediary) antara satuansatuan kumpulan masyarakat atau unit-unit ekonomi yang mengalami kelebihan dana ( surflus unit) dengan unit-unit lain yang megalami kekurangan dana (deficit unit), melalui bank kelebihan dana -dana tersebut bisa disalurkan kepada pihak-pihak yang memerlukan dan memberikan manfaat kepada kedua belah pihak. Bank Syariah memainkan peran yang sangat vital dan strategis. Eksistensi Bank Syariah dapat dijadikan sebagai salah satu dari indikator perkembangan ekonomi Islam. Semakin besar market share perbankan syariah, maka semakin banyak komponen dalam masyarakat yang menggunakan berbagai transaksi syariah. 
Komposisi sumber dana yang dihimpun Bank Syariah setidaknya terdiri dari tiga komponen, yaitu modal, pinjaman antar bank dan DPK ( Dana Pihak Ketiga), dana yang terhimpun dari masyarakat merupakan komponen terpenting dalam penghimpunan dana (funding) di dunia perbankan.

Sumber dana dari masyarakat ini disebut dengan simpanan atau Dana Pihak Ketiga (DPK), yang dalam UU No. 21 tahun 2008 Bab I ayat 20 didefinisikan sebagai dana yang dipercayakan oleh nasabah kepada Bank Syariah dan/atau UUS berdasarkan akad wadi'ah atau akad lain yang tidak bertentangan dengan prinsip syariah dalam bentuk Giro, Tabungan, atau bentuk lainnya yang dipersamakan dengan itu.

Salah satu jenis Dana Pihak Ketiga adalah Tabungan, sesuai dengan undang- undang No, 10 tahaun 1998 tentag Perbankan pada Pasal 1 ayat 9 pengertian Tabungan adalah simpanan yang penarikannya hanya dapat dilakukan menurut syarat tertentu yang disepakati, tetapi tidak dapat ditarik dengaan cek, bilyet giro, dan atu alat lainnya yang dipersamakan dengan itu, sedangkan pengertian tabungan sesuai UU No. 21 tahun 2008 tentang Perbankan Syariah pada pasal 1 ayat 21 pengertian Tabungan adalah simpanan berdasarkan akad wadi'ah atau investasi dana berdasarkan akad mudharabah atau akad lain yang tidak bertentangan dengan prinsip syariah yang penarikannya dapat dilakukan sesuai dengan ketentuan yang sudah disepakati

\section{Akad Tabungan Syariah}

Akad tabungan Syariah berdasarkan Fatwa Dewan Syariah Nasioanl adalah Tabungan yag berdasarkan prinsip Wadiah dan Mudharabah. Sedangkan menurut Adiwarman Karim Tabungan Wadiah adalah tabungan yang dijalankan berdasarkan akad wadiah, yakni titipan murni yang harus dijaga dan dikembalikan setiap saat sesuai dengan kehendak pemiliknya ( Adiwarman Karim : 2009) , kaitan degan produk tabungan wadiah bank syariah mengunakan akad wadiah yad adh-dhamanah dalam hal ini nasabah bertindak sebagai penitip yang memberikan hak kepada bank syariah untuk menggunakan atau memanfaatkan uang titipannya sedangkan bank syariah bertindak sebagai pihak yang dititipi dana yang disertai hak untuk menggunakan atau memanfaatkan dana sebagai konsekwensinya bank bertanggung jawab terhadap keutuhan dana titipan tersebut , serta mengembalikannya kapan saja sesuai yang dikenhendaki pemiliknya. Disisi lain bank juga berhak sepenuhnya atas keuntungn dari hasil penggunaan atau pemanfaatan dana tersebut. Akad wadiah Ya dahamanah ini mempunyai implikasi hukum yag sama dengan qard, maka nasabah penitip dan bank tidak boleh saling menjanjikan untuk membagihasilkan keuntungan dana tersebut, namun demikian bank diperkenankanmemberikan bonus kepada pemilik dana titipan selama tidak disyaratkan di muka, dengan kata lain pemberianbonus merupakan kebijakan bank syariah semata yang bersifat suka rela.

Sedangkan tabungan atas dasar akad Mudharabah adalah tabungan yang dijalankan dengan menggunakan akad mudharabah akad mudahaabah sendiri terbagi menjadi dua yaitu mudharabh Mutlaqah dan mudharabah Muqayadah yang perbedaan yang utama diantara keduanya terletak pada ada atau tidaknya persyaratan yang diberikan pemilik dana kepada bank dalam mengelola dananya dalam hal ini bank syariah bertidak sebagai mudharib (pegelola dana) sedangkan nasabah bertindak sebagai shahibul mal (pemilik dana) bank syariah dalam kapasitasnya sebagai mudharib mempunyai kuasa untukmelakukan berbagai macam usaha yang tidak bertetangan dengan prinsip syariah serta mengembangkannya termasuk melakukan akad mudharabah dengan pihak lain(menyalurkan dana) namun disisi lain bank syariah juga memiliki sifat sebagai wali amanat yang berarti bank harus berhatihati atau bijaksana serta beritikad baik dan bertanggungjawab atas segala sesuatu yang timbul akbat kesalahan dan kelalaiannya. Dari hasil pengelolaan dana mudharabah bank syariah akan membagihasilkan kepada pemilik dana sesuai dengan nisbah yang telah disepakati dan dituangkan dalam akad pembukaan rekening.

\section{Kerangka Pemikiran}

Sebagai manusia yang hidup di muka bumi ini harus memahami dan menyadari bahwa untuk menyempurnakan iman kepada Allah dan dalam ranka mengharapkan ridhaa -Nya, dia harus berbuat dan bertingah laku dalam kehidupannya sesuai dengan yang Allah perintahkan dengan kata lain harus sesuai dengan kehendak Allah SWT. Kehendak Allah tersebut disampaikan-Nya dalam Al Quran dan penjelasan yang dberikan Rasul dalam sunnahnya dalam semua asfek kehidupan, baik yang menyangkut hubungan manusia dengan Allah asfek ini disebut Ibadah, maupun asfek hubungan manusia dengan manusia dan alam sekitarnya yang disebut muamalat dalam artian umum. Pedoman yang berhubungann dengan sesama manusaia itu ada yang berkaitan dengan usahanya mendapatkan keturunan yang baik yan disebut munakahat atau yang berkaitan dengan harta dan cara memperolehnya yang disebut muamalat dalam artian khusus, atau yang berkaitan dengan rasa aman dan perlindungan dalam kehidupannya yang disebut dengan jinayat.

\section{Al-Qur' an surah An-nisa ayat 59 dan surah Al-maidah ayat 49.}




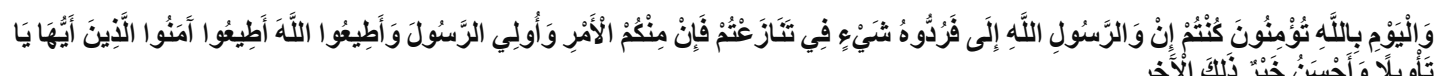

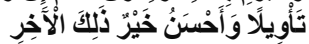

Terjemah : Hai orang-orang yang beriman, taatilah Allah dan taatilah Rasulnya dan ulil Amri di antara kamu. Kemudian jika kamu berlainan pendapat tentang sesuatu, maka kembalikanlah ia kepada Allah dan rasulnya, jika kamu benar-benar beriman kepada Allah dan hari kemudian. Yang demikian itu lebih baik bagimu dan lebih baik akibatnya.

Berkaitan dengan masalah muamalah secara khusus yaitu hubungan manusaia dengan sesama manusia yang terkait masalah harta dan cara memperolehnya salah satu contoh dalam kehidupa sehari-hari adalah ketika seseorang melakukan transaksi dan berinteraksi dengan dunia perbankan khusunya ketika seseorang ingin menyimpan dananya dalam bentuk tabungan di perbankan dengan berbagai tujuan diantaranya untuk investasi, pembayaran, simpanan sebagai seorag muslim tentunya ada aturan yang berkitan dengan masalah tersebut yaitu bagaimana memilih bank yang sesuai dengan kaidah Islam.

Dalam rangka menghimpun dana masyarakat dalam bentuk simpanan salah satunya dalam bentuk tabungan, bank-bank konvensianal akan berusaha semaksimal mungkin untuk bisa menghimpun dana masyarakat tersebut dengan berbagai upaya diantaranya yaitu :

1. Pemberian bunga yang tinggi

2. Penggunaan teknologi yang cangggih

3. Meningkatkan pelayanan

4. Pembukaan kantor-kantor cabang dan cabang pembantu

5. Pemberian hadiah

Walaupun bank-bank konvensional telah melakukan upaya-upaya untuk bisa menghimpun dana dari masyarakat dalam bentuk tabungan, ternyata untuk sebagian orang atau masyarakat hal tersebut bukanlah sesuatu yang bisa mempengaruhi dirinya untuk berintersi dan bertransaksi dengan bank konvensiaonl, mereka lebih tertarik untuk menabung di perbankan syariah dengan petimbangan :

1. Dengan menabung di perbankn syariah lebih berkah walaupun keuntungan secara materi yang diperoleh dari tabungan perbankan syariah lebih kecil dari keuntungan di bank konvensional, karena materi bukanlah segala-galanya yang terpenting adalah mendapat ridha dan keberkahan dari Allah SWT.

2. Dengan menabung di perbankan syariah bisa membantu sesama muslim, karena uang yang ditabungkan di bank syariah diyakini akan disalurkan kepada sesama muslim dan untuk membiayai atau membantu usaha-usaha yang yang tidak bertentangan dengan ketentuan syariah

Faktor atau hal yang menjadi alasan mereka untuk tetap menabung di perbankan syariah adalah adanya Intangible value yang terdiri atau yang mencakup elemen-elemen :

1. Kesesuaian Aqidah

2. Kemanfaatan Sosial

3. Ketersediaan Pilihan dan Fasilitas

4. Pelayanan dan Personalitas Petugas

\section{Kesesuaian Aqidah}

Sebagai seorang muslim yang kaffah tentunya ketika akan melakukan interaksi atau bertransaksi dengan sebuah bank untuk melakukan aktivits menabung tentunya harus mempunyai kriteria bank mana yang akan dijadikan mitra, tentunya kita harus memilih bank yang menjalankan operasionalnya sesuai tuntunan syariah, yaitu bank syariah. Produk-produk yang ada di perbankan syariah diyakini sesuai dengan aturan Islam yaitu sesuai degan Al Quran dan Sunah Rosul, produk Tabungan di perbankan syariah jauh dari nilai-nilai yang melangar ketentuan syariah yaitu dintaranya :

1. Ada unsur mengandung Riba

2. Ada unsur Ghoror

3. Ada unsur Maisyir

4. Ada unsur Bathil

Adapun dalil dalil pruduk tabungan di perbankan syariah sesuai Fatwa Dewan Syariah Nasional adalah sebagai berikut :

1. Firman Allah QS. al-Nisa' [4]: 29:

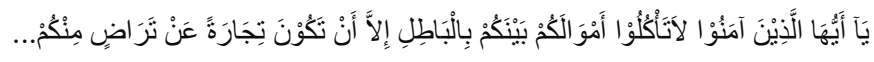


"Hai orang yang beriman! Janganlah kalian saling memakan (mengambil) harta sesamamu dengan jalan yang batil, kecuali dengan jalan perniagaan yang berlaku dengan sukarela di antaramu...”.

2. Firman Allah QS. al-Baqarah [2]: 283:

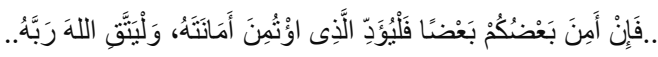

“...Maka, jika sebagian kamu mempercayai sebagian yang lain, hendaklah yang dipercayai itu menunaikan amanatnya dan hendaklah ia bertakwa kepada Allah Tuhannya...".

3. Firman Allah QS. al-Ma'idah [5]: 1:

"Hai orang yang beriman! Penuhilah akad-akad itu ...".

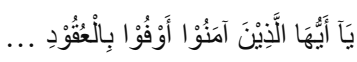

4. Hadis Nabi riwayat Ibnu Majah:

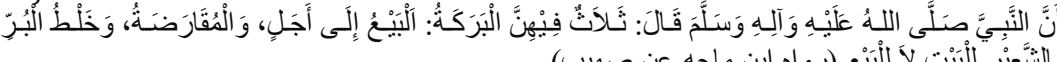

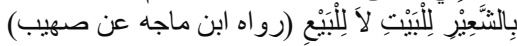

"Nabi bersabda, 'Ada tiga hal yang mengandung berkah: jual beli tidak secara tunai, muqaradhah (mudharabah), dan mencampur gandum dengan jewawut untuk keperluan rumah tangga, bukan untuk dijual."' (HR. Ibnu Majah dari Shuhaib).

5. Ijma. Diriwayatkan, sejumlah sahabat menyerahkan (kepada orang, mudharib) harta anak yatim sebagai mudharabah dan tak ada seorang pun mengingkari mereka. Karenanya, hal itu dipandang sebagai ijma' (Wahbah Zuhaily, al-Fiqh al-Islami wa Adillatuhu, 1989, 4/838).

6. Qiyas. Transaksi mudharabah diqiyaskan kepada transaksi musaqah.

7. Kaidah fiqh:

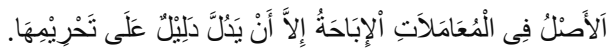

"Pada dasarnya, semua bentuk muamalah boleh dilakukan kecuali ada dalil yang mengharamkannya."

8. Para ulama menyatakan, dalam kenyataan banyak orang yang mempunyai harta namun tidak mempunyai kepandaian dalam usaha memproduktifkannya; sementara itu, tidak sedikit pula orang yang tidak memiliki harta namun ia mempunyai kemampuan dalam memproduktifkannya. Oleh karena itu, diperlukan adanya kerjasama di antara kedua pihak tersebut.

\section{Kemanfaatan Sosial}

Yang menjadi pertimbangan untuk melakukan aktivitas menabung di bank syariah yaitu menyakini bahwa dana yang ditabungkan di bank syariah akan mempunyai nilai manfaat bagi sesama muslim dan dana tersebut tentunya akan digunakan untuk usaha-usaha yang tidak bertentangan dengan ketentuan syariah, dengan demikian sebagai seorang muslim kita sudah menjalankan amanah dari Allah atas harta yang kita miliki, sehinga harta atau dana kita yag disimpan di bank syariah bermanfaat bagi orang lain. Hal ini sesuai dengan firman Allah

Firman Allah QS. al-Ma'idah [5]: 2:

"dan tolong-menolonglah dalam (mengerjakan) kebajikan...."

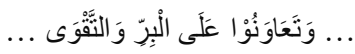

Allah SWT akan memberikan pelayanan surga kepada orang yang menolong meringankan beban hidup orang lain. Perhatikan hadits berikut ini: "Sesiapa yang bersikap ramah kepada orang lain dan meringankan beban hidupnya baik sedikit maupun banyak maka kewajiban bagi Allah untuk memberikan kepadanya pelayanan dengan pelayanan surga" (HR Thabrani).

\section{Ketersediaan Pilihan dan Fasilitas}

Masyarakat terutama yang berada di sekitar wilayah kantor bank syariah yang berlokasi di daerah yang sangat terbatas jumlah bank yang beropersi, maka bank syariah menjadi pilihan yang utama untuk melakukan transaksi atau berinteraksi terutama dalam melakukan tabungan

\section{Pelayanan dan Personalitas Petugas}

Yang menjadi pertimbangan untuk melakukan aktivitas menabung di bank syariah yaitu pelayanan dan personalitas petugas yang dirasakan sangat bersahabat dengan nasabah, para petugas bank menganggap nasabah adalah mitra kerja mereka, hal-hal yang cukup menyentuh para nasabah yang dilakukan oleh para petugas adalah petugas sering melibatkan nasabah dalam even-even tertentu, dalam kegiatan kantor maupunn kegiatan pribadi petugas bank. 


\section{Intangible Value Berdasarkan Perspektif Metodologi Tawhid String Relation}

Prof. Choudhury M.A., melakukan re-inventing atas epistemologi islam (islamic epistemology), yang mendasarkan pemikiran paradigma universal bahwa ilmu dan kebenaran berasal di alam semesta ini berasal dari Allah SWT. Pernyataan, keyakinan dan keimanan atas Allah yang bersifat Tunggal atau Esa disebut Tauhid. Karena semua ilmu adalah berasaal dari Allah, maka kesatuan atas ilmu dan pengetahuan tersebut (unified of knowledge) menjadi kausalitas yang mutlak. Ilmu Allah SWT terdapat dalam Al'Quran dan Hadist yang secara tersirat dan tersurat merupaka ilmu yang lengkap dan sempurna, meliputi ruang lingkup yang terbesar sebagai alam semesta dan lingkup yang berukuran terkecil (nanometric dan gigantic), dimensi ilmu dunia dan akherat.

Ilmu Allah adalah topologi kosmos dari segala kebenaran di dunia ini, dan secara konsensus diberi notasi atau simbul sebagai $\Omega$ (omega). Dengan tidak mengingkari atas ilmu empiris dan berbagai pengembangan ilmu yang berdasarkan akal pikiran maupun intuisi manusia, kebenaran bisa digambarkan melalui suatu proses knowledge induced- $(\theta)$, dan digambarkan dengan baik oleh Choudhury MA sebagai berikut:

$\Omega \rightarrow \mathrm{s} \equiv\left((\Omega, \mathrm{S}) \rightarrow\right.$ (discourse) Primal $\theta \rightarrow \mathbf{x}(\theta) \rightarrow \theta_{\text {ranks }} \rightarrow \mathrm{W}(\mathbf{x}(\theta)) \rightarrow$ continuity

Ilmu Allah $(\Omega)$, melalui suatu tahapan shuratic process $(S)$, pada kasus atau kondisi yang dikendaki olehNYA, dialirkanlah ilmu Allah $(\theta$ ) kepada variabel (Xi) sehingga variabel tersebut menjadi variabel yang kaffah, mempunyai dimensi kebenaran dunia dan akherat $(\mathrm{Xi}(\theta))$. Dalam sustu set atau himpunan W(Xi) yang terdiri dari berbagai variabel juga terjadi knowledge induced yang serupa, sehingga menjadi $\mathrm{W}(\mathrm{Xi}(\theta), \theta)$, dalam hal ini disebut sebagai wellbeing atau maslahah.

Pada prinsipnya, proses kebenaran itu pada akhirnya bermuara pada level kesejahteraan umat, dengan dimensi yang kaffah, dunia akherat. Kesejahteraan juga merupakan ukuran pencapaian atas materials dan non-material, dengan satuan pengukuran secara kuantitatif dan kualitatif.

Suriadi (2013) dalam kajian akademis mengenahi uraian TSR, mengungkapkan beberapa prinsip dasar sebagai suatu premis dengan analogi kasus berdasarkan data empiris dilapangan, menyebutkan premis TRS meliputi: 1). Complexity and endogeneity; 2).Participatory among agents, 3). Wellbeing function. Ke-3 premis dasar tersebut dengan analogi metode ekonometrik dikembangkan untuk melakukan suatu pengukuran yang berbasis pada wellbeing atau masllahah.

\section{Complexity and Endogeneity}

Bila diperhatikan dengan cermat bintang bintang di langit pada malam hari, tidakkah akal dan pikiran kita bertanya tanya, siapakah Maha Pengatur alam semesta, jagat raya galaksi makro kosmis sehingga benda benda itu bergerak teratur harmoni mengikuti hukum alam yang demikian kompleks. Tuntu saja Allah Maha Pencipta, Maha Pengatur atas benda benta alam semesti ini. Baik benda hidup maupun benda mati, maka wajar saja akal pikiran kita (umat manusia) menerima kenyataan, bahwa setiap makhluk yang diciptakan oleh Allah, tentu mempunyai manfaat, atau kegunaan terhadap yang lain.

Contoh lain yang membukakan mata dan pikiran kita, manakala kita menyaksikan film wild world dimana interaksi, hubungan sebab akibat, dan berbagai proses kehidupan antar komponen makhluk hidup dalam hutan belantara mengikuti kaidah hukum alam. Kehidupan dan kematian merupakan suatu proses dan siklus yang sedemikan erat berkaitan. Memakan dan dimakan dengan ukuran alamiah yang luar biasa sempurna, tiada yang tersisa dengan sia-sia atas suatu kejadian. Singa memangsa Zebra misalnya, dalam proses satu kematian dan dimanfaatkan dalam mendukung kehidupan yang lain. Secara keseluruhan dan garis besar rantai makan terkait dengan rantai kehidupan dan kematian. Tak ada yang sia sia.

Sebagai manusia, makhluk yang paling mulia yang diciptakan oleh Allah dimuka bumi ini, kita umat manusia dibekali hal penting yang tidak diberikan oleh makhluk lain (para termasuk para Malaikat), yaitu akal pikiran dan hati nurani. Manusia adalah khalifah atau pemimpin dimuka bumi ini. Akal pikiran dan hati nurani manusi adalah semacam software pemandu agar bisa menjaga bumi dan seisinya berjalan dengan baik sesuaai yang dikehendaki oleh Sang Khalik. Akal digunakan untuk mempelajari segala segala peristiwa alam dan hati adalah penyelarasnya.

Kenyataan empiris, ilmu pengetahuan hasil pikiran para ilmuwan, skill atau keahlian dalam menghadapi dan mengatasi permasalahan di segala aspek kehidupan sehari hari , memberi pelajaran yang sangat berarti dalam memahami peran manusia dan peran Allah sebagai Sang Pencipta. Pemahaman yang benar akan mengantarkan sikap, kepercayaan dan perilaku yang benar. Dan seterusnya hingga manusia bisa dan mampu menjalani kehidupan dengan benar.

Salah satu hal penting yang mendasari konsep dan kerangka pemikiran dan kemudian dikemas dalam premis complexity adalah kenyataan empiris yang secara jelas menunjukkan adanya hubungan yang erat dan saling mempengaruhi antar beberapa hal penting (selanjutnya disebut sebagai variabel 
atau Xi) dalam kehidupan manusia. Terutama dalam sudah pandang ilmu sosial, termasuk kajian ekonomi dan keuangan baik pada tataran personal ataupun institusi.

Premis complexity menjelaskan bahwa persoalan hubungan dan interaksi variabel Xi dalam suatu sistem, adalah suatu hubungan sangat kompleks, komprehensif, interdependensi dan diidentifikasi membentuk interaksi reciprocal causality. Satu variabel menjadi faktor penyebab atau mempengaruhi variabel yang lainnya dan demikian sebaliknya. Bila ada dua variabel dalam satu sistem, katakanlah X1 adalah ukuran "tingkat pendidikan" dan X2 adalah "tingkat penghasilan" masyarakat, maka hubungan tersebut bisa digambarkan dalam bentuk notasi sebagai berikut:

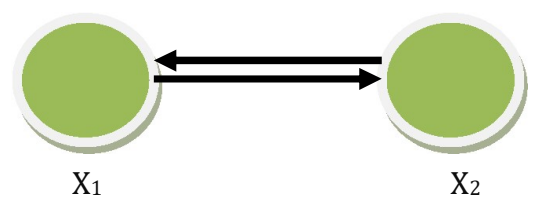

Dan dalam bentuk konstruksi atau model matematis di formulasikan sebagai berikut:

$\mathrm{X}_{1}=\int 1\left(\mathrm{X}_{2}\right)$, dibaca $\mathrm{X}_{1}$ merupakan fungsi (atau dipengaruhi oleh) $\mathrm{X}_{2}$

$\mathrm{X}_{2}=\int 2\left(\mathrm{X}_{1}\right)$, dibaca $\mathrm{X}_{2}$ merupakan fungsi (atau dipengaruhi oleh) $\mathrm{X}_{1}$

Kedua model persamaan tersebut diatas adalah benar, yang bisa divalidasi dari bukti empiris dan dianalisis secara intuitif oleh akal dan hati kita.

Pertanyaan selanjutnya adalah apakah hubungan dua variabel selalu bersifat reciprocal atau timbal balik seperti itu? Jawaban yang mungkin didapatkan akan sangat bervariasi, ya, mungkin, sering, jarang, tidak, ya asal begini begitu dan seterusnya. Akan banyak hal alasan dan argumentasi yang dikemukakan bersifat kondisional atau sering dikatakan dengan istilah "tergantung". Contoh nyata adalah sebagai berikut: bila si A menerima uang satu juta rupiah dari si B, apakah si B akan menerima uang sejumlah yang sama dari si B. Berdasarkan akal pikiran dan bukti empiris dilapangan, tentu saja jawabnya tidak. Sebagaimana bahwa $X 1=\int 1(X 2)$ dan $X 2=\int 2(X 1)$ adalah suatu sistem yang menggunakan fungsi berbeda atau bisa dikataan fugsi $\int 1$ dan $\int 2$ berbeda.

Namun demikian, bagi banyak juga umat Islam di Indonesia atau pun kaum Muslim dari berbagai penjuru dunia yang memiliki pemahaman dan keyakinan yang komprehensif, dimana persoalan kehidupan didunia ini tidak hanya dikerangkakan dan diformulasikan dalam bentuk terdiri dari 2 variabel saja, bisa 3, bisa banyak dan bahkan bisa tidak terhingga.

Dalam penjelasan atas gambaran diatas bahwa, bila kita memberi sesuatu (sedekah) atau berbuat kebajikan dengan orang lain, dalam suatu sistem dengan variabel yang banyak sekali, maka akan ada efek kembali ke kita, apakah respon secara langsung dari orang yang bersangkutan atau secara tidak langsung dari orang lain yang berada dalam satu sistem.

Maka logis kiranya jika konsep sedekah seperti disosialisasikan oleh Ustat Yusuf Mansyur melalui dakwahnya, bertemakan "kekuatan sedekah". Allah akan membalasnya, melalui berbagai jalan atau perantara orang lain. Konsep kekuatan sedekah secara rasional mendapatkan similaritasnya, dalam konsep dan kerangka pemahaman "complexity"

\section{Wellbeing Function}

Ilmu (ekonomi) secara empiris yang dikembangkan oleh manusia pada umumnya hanya bersifat duniawi dan hanya fokus pada perhitungan materialistis saja. Para ekonom Muslim mulai mengembangkan suatu metoda baru yang sesuai dengan akhlak dan aqidah umat Islam. Perlu suatu pemahaman, bahwa supaya ilmu tersebut diatas menjadi kaffah dan berdimensi dunia akherat, maka semua terminologi dan definisi ilmu empiris yang dipercaya kebenarannya dengan menggunakan akal pikiran manusia yang terbatas perlu di lakukan induced oleh ilmu Allah yang tidak terbatas (Al-qur'an dan hadits). (Choudhury, 2011:30), menjabarkan proses mengalirnya ilmu (S) berupa Knowledge induced $(\theta)$ dari ilmu Allah $(\Omega)$ sebagai, berikut :

$$
\Omega \rightarrow s \equiv\left((\Omega, S) \rightarrow \text { (discourse) Primal } \theta \rightarrow \mathbf{x}(\theta) \rightarrow \theta_{\text {ranks }} \rightarrow \mathrm{W}(\mathbf{x}(\theta)) \rightarrow\right. \text { continuity ..... }
$$

Dalam pemahaman ilmu sosial yang dinamis, maka obyek pengamatan adalah sebuah besaran dalam variable yang teridentifikasi bukan hanya nilai dimensi besaran/ uurannya saja, tapi juga berupa dimensi lain, yaitu arah atau kecenderungan bergerak. Dengankata lain variabel adalah sebuahvector. Nilai dari variabel $\mathrm{X}$ kemudian harus dibaca sebagai vector $\{\theta, \mathbf{X}(\theta)\}$, dimana $(\theta)$ adalah knowledge flow dari ilmu Allah ( $\Omega$, cardinal stock) atas variabel empiris $(\mathrm{X})$.

Proses induced $(\theta)$ dari variabel sebagai individual (bukan dipandang sebagai sistem) digambarkan secara notasi sebagai berikut: 
$\mathbf{X}_{\mathbf{i}}+(\theta)$-------------------- $\rightarrow \mathbf{X}_{\mathbf{i}}(\theta)$

Sedangkan proses induced $(\theta)$ dari suatu sistem yang terdiri dari beberapa variabel (Xi) digambarkan sebagai berikut:

$\mathbf{f}\left(\mathbf{X}_{\mathbf{i}}\right)+(\theta)---\cdot--\cdot----\rightarrow f\left(\theta, \mathbf{X}_{\mathbf{i}}(\theta)\right)$

Dalam suatu sistem yang telah diidentifikasi anggota sub-sistem atau variabel, sebagaimana tersebut diatas, maka bisa digambarkan sebagai berikut:

$\mathbf{f}\left(\mathbf{X}_{1}, \mathbf{X}_{2}, \mathbf{X}_{3}, \mathbf{X}_{\mathbf{4}}, \mathbf{X}_{\mathbf{n}}\right)+(\theta)----\rightarrow \mathbf{f}\left(\mathbf{X}_{\mathbf{1}}(\theta), \mathbf{X}_{\mathbf{2}}(\theta), \mathbf{X}_{\mathbf{3}}(\theta), \mathbf{X}_{\mathbf{4}}(\theta), \mathbf{X}_{\mathbf{n}}(\theta),(\theta)\right)$

Secara statistik, dari 5 set data original, setelah mengalami proses induced $(\theta)$ set data dijabarkan kembali dan menjadi 6 set data. Data yang baru terbentuk adalah data $(\theta)$. Data $(\theta)$ bisa didapatkan secara ilmiah dengan menggunakan indek $(\theta)$ yang pada prinsipnya adalah suatu index yang berisi esensi kebaikan atau kebajikan dari semua data variabel yang ada dalam sistemm.

Selanjutnya, setelah data variabel dalam sistem yang baru tersusun kembali, semua variabel tersebut mengalami proses kembali ke "Premis 1 TSR", maka akan didapatkan suatu fungsi sebagai berikut:

$\mathbf{X}_{1}(\theta)=\mathbf{f}\left(\mathbf{X}_{1}(\theta), \mathbf{X}_{2}(\theta), \mathbf{X}_{3}(\theta), \mathbf{X}_{4}(\theta), \mathbf{X}_{\mathbf{n}}(\theta),(\theta)\right)$

$\mathbf{X}_{2}(\theta)=\mathbf{f}\left(\mathbf{X}_{1}(\theta), \mathbf{X}_{2}(\theta), \mathbf{X}_{3}(\theta), \mathbf{X}_{4}(\theta), \mathbf{X}_{\mathbf{n}}(\theta),(\theta)\right)$

$\mathbf{X}_{3}(\theta)=\mathbf{f}\left(\mathbf{X}_{1}(\theta), \mathbf{X}_{2}(\theta), \mathbf{X}_{3}(\theta), \mathbf{X}_{4}(\theta), \mathbf{X}_{\mathbf{n}}(\theta),(\theta)\right)$

$\mathbf{X}_{4}(\theta)=\mathbf{f}\left(\mathbf{X}_{1}(\theta), \mathbf{X}_{2}(\theta), \mathbf{X}_{3}(\theta), \mathbf{X}_{4}(\theta), \mathbf{X}_{\mathbf{n}}(\theta),(\theta)\right)$

$\mathbf{X}_{\mathbf{5}}(\theta)=\mathbf{f}\left(\mathbf{X}_{\mathbf{1}}(\theta), \mathbf{X}_{\mathbf{2}}(\theta), \mathbf{X}_{3}(\theta), \mathbf{X}_{\mathbf{4}}(\theta), \mathbf{X}_{\mathbf{n}}(\theta),(\theta)\right)$

$\mathbf{X}_{\mathbf{6}}(\theta)=\mathbf{f}\left(\mathbf{X}_{1}(\theta), \mathbf{X}_{2}(\theta), \mathbf{X}_{3}(\theta), \mathbf{X}_{4}(\theta), \mathbf{X}_{\mathbf{n}}(\theta),(\theta)\right)$

$\mathbf{X}_{\mathbf{n}}(\theta)=\mathbf{f}\left(\mathbf{X}_{1}(\theta), \mathbf{X}_{2}(\theta), \mathbf{X}_{3}(\theta), \mathbf{X}_{4}(\theta), \mathbf{X}_{\mathbf{n}}(\theta),(\theta)\right)$

$(\theta)=\mathbf{f}\left(\mathbf{X}_{1}(\theta), \mathbf{X}_{2}(\theta), \mathbf{X}_{3}(\theta), \mathbf{X}_{4}(\theta), \mathbf{X}_{\mathbf{n}}(\theta)\right)$

Kemudian kembali ke "Premise 2 TSR", data diolah dengan dengan menggunakann kaidah PAA dan hasilnya adalah sebagai berikut:

$$
\begin{aligned}
& \Delta \mathrm{X}_{1}(\theta)=\mathrm{k} 1 \mathrm{X}_{1}(\theta)+\mathrm{k} 2 \mathrm{X}_{2}(\theta)+\mathrm{k} 3 \mathrm{X}_{3}(\theta)+\mathrm{k} 4 \mathrm{X}_{4}(\theta) \ldots+\mathrm{kn} \mathrm{X}_{5}(\theta)+\mathrm{k} 0(\theta) \\
& \Delta \mathrm{X}_{2}(\theta)=\mathrm{k} 1 \mathrm{X}_{1}(\theta)+\mathrm{k} 2 \mathrm{X}_{2}(\theta)+\mathrm{k} 3 \mathrm{X}_{3}(\theta)+\mathrm{k} 4 \mathrm{X}_{4}(\theta) \ldots+\mathrm{kn} \mathrm{X}_{5}(\theta)+\mathrm{k} 0(\theta) \\
& \Delta \mathrm{X}_{3}(\theta)=\mathrm{k} 1 \mathrm{X}_{1}(\theta)+\mathrm{k} 2 \mathrm{X}_{2}(\theta)+\mathrm{k} 3 \mathrm{X}_{3}(\theta)+\mathrm{k} 4 \mathrm{X}_{4}(\theta) \ldots+\mathrm{kn} \mathrm{X}_{5}(\theta)+\mathrm{k} 0(\theta) \\
& \Delta \mathrm{X}_{4}(\theta)=\mathrm{k} 1 \mathrm{X}_{1}(\theta)+\mathrm{k} 2 \mathrm{X}_{2}(\theta)+\mathrm{k} 3 \mathrm{X}_{3}(\theta)+\mathrm{k} 4 \mathrm{X}_{4}(\theta) \ldots+\mathrm{knX}_{5}(\theta)+\mathrm{k} 0(\theta) \\
& \Delta \mathrm{X}_{5}(\theta)=\mathrm{k} 1 \mathrm{X}_{1}(\theta)+\mathrm{k} 2 \mathrm{X}_{2}(\theta)+\mathrm{k} 3 \mathrm{X}_{3}(\theta)+\mathrm{k} 4 \mathrm{X}_{4}(\theta) \ldots+\mathrm{knX}_{5}(\theta)+\mathrm{k} 0(\theta) \\
& \Delta \mathrm{X}_{\mathrm{n}}(\theta)=\mathrm{k} 1 \mathrm{X}_{1}(\theta)+\mathrm{k} 2 \mathrm{X}_{2}(\theta)+\mathrm{k} 3 \mathrm{X}_{3}(\theta)+\mathrm{k} 4 \mathrm{X}_{4}(\theta) \ldots+\mathrm{knX}_{5}(\theta)+\mathrm{k} 0(\theta) \\
& \Delta(\theta)=\mathrm{k} 1 \mathrm{X}_{1}(\theta)+\mathrm{k} 2 \mathrm{X}_{2}(\theta)+\mathrm{k} 3 \mathrm{X}_{3}(\theta)+\mathrm{k} 4 \mathrm{X}_{4}(\theta) \ldots . .+\mathrm{knX}_{\mathrm{n}}(\theta)+\mathrm{k} 0(\theta)
\end{aligned}
$$

Dalam konteks fokus pengukuran, maka yang selalu dipilih sebagai dependent variable adalah $(\theta)$, dan dengan tidak merubah kontennya, notasi $(\theta)$ dalam fungsi sebagai dependent variable ditransformasikan menjadi menjadi $\mathrm{W}(\theta)$ dan dipahami sebagai Wellbeing function. Sehinga persamaan final Wellbeing Function adalah sebagai berikut :

\section{$\Delta \mathbf{W}(\theta)=\mathbf{k} 6(\theta)+\mathbf{k} 1 \mathbf{X}_{1}(\theta)+\mathbf{k} 2 X_{2}(\theta)+\mathbf{k}_{3} X_{3}(\theta)+\mathbf{k} 4 X_{4}(\theta) \ldots \mathbf{k n}_{\mathbf{n}}(\theta)$}

a. $\Delta \mathrm{W}(\theta)$ adalah perubahan nilai Wellbeing atas suatu sistem

b. X1 adalah nilai "Pengukuran/skor Kinerja" variabel X1

c. K1 adalah bobot atau tingkat partisipasi variabel X1 dalam sistem

d. $(\theta)$ adalah ukuran persepsi moralitas, etika dan nilai nilai sosial yang melekat pada setiap variabel

e. $\mathrm{K} 6(\theta)$ adalah faktor ekternal yang tidak bisa dijelaskan oleh semua variabel yang ada dalam sistem.

Premis TSR secara keseluruhan dibaca:

"Dalam sebuah sistem yang sudah dilakukkan knowledge induced-( $\theta$ ), maka Wellbeing (atau kemasalahatan, kebajikan, kebaikan) merupakan partisipasi seluruh komponen variabel yang telah knowledge induced- $(\theta)$, dan komponen $(\theta)$ itu sendiri yang diartikan sebagai suatu pengaruh atau penentu ekternal atau diinterpretasikan sebagai diluar kemampuan manusia atau "Rahasia/Takdir Allah".

\section{Wellbeing Sebagai Fokus Pengukuran}

Bila diperhatikan dengan seksama, persamaan dalam (2.5) tersebut diatas sudah sesuai dengan persamaan yang dikerangkakan pada (1.6), dimana sebagai dependent variable adalah suatu ukuran wellbeing yang diinterprestasikan sebagai kemaslahatan umat. Hal ini menunjukan suatu pemahaman bahwa, dengan metodologi TSR selalu merujuk wellbeing sebagai objek utama dalam segala hal pengukuran dalam kegiatan manusia. Tujuan utama atau sasaran atas pengukuran apapun harusnya 
merupakan suatu kondisi yang berdimensi kemaslahatan umat. Berikikan kebajikan, bukan saja pada sisi duniawi, akan tetapi juga pada dimensi ukhrowi.

Secara rasionalital, pemaknaan wellbeing sebagai dependent variable, juga berarti bahwa design sistem atau strategi organisasi haruslah mencakup sutu dimensi yang lebih holistik. Hal ini mencakup semua sistem pengukuran atas semua variabel yang terlibat didalam sisteim tersebut. Dalam konteks BPRS, bahwa kinerja hendaknya diukur tidak saja pada dimensi keuangan sesuai dengan kehendak pemilik (shareholders) tetapi harus meliputi semua sektor yang melibatkan semua yang terkait dengan organisasi (stakeholders)

Dalam objek pengamatan yang akan mendaji dasar evaluasi mengenahi margin tabungan, di daearah sekitar operasional BPRS Muamalat Harkat, telah ada cabang bank BNI dimana masyarakat mempunyai akses untuk menabung. Dalam hal margin atau imbal bagi hasil atas keuntungan dari dana tabungan diperoleh data sebagai berikut:

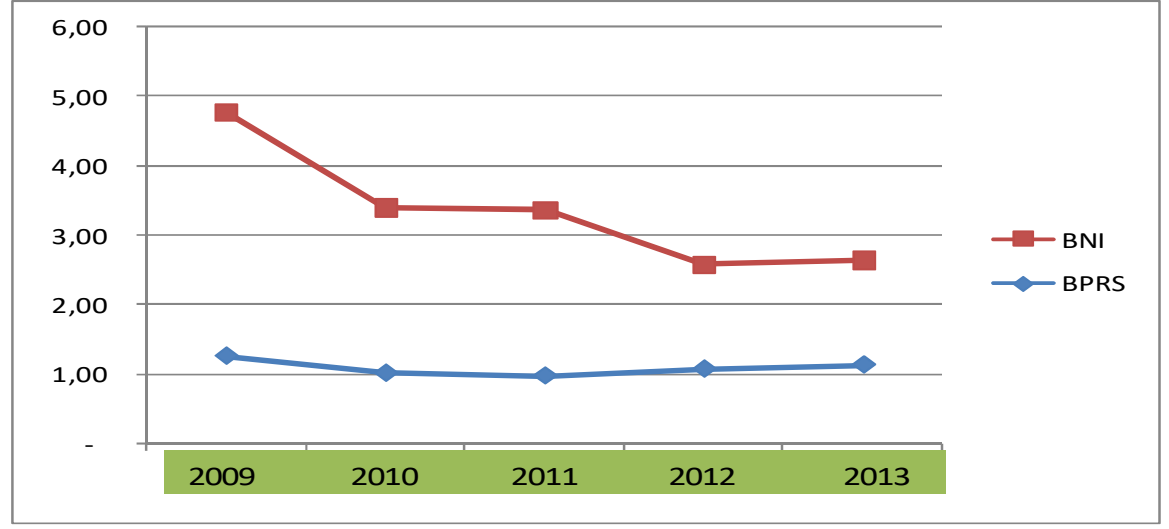

Tabel 2: Perbandingan Margin Tabungan BNI Vs BPRS

Jelas terlihat bahwa ukuran rasionalitas margin BPRS selalu kalah dengan bank BNI, dan menjadi sutau pertanyaan yang mendasar mengapa masih banyak orang yang menabung di BPRS? Berdasarkan teori dan konsep pemikiran metodologi TSR jelas digambarkan suatu kaidah pokok atas ilmu yang berbasis rasionalitas (mainstream) harus dilakukan atau embbeded pada esnsi ilmu Allah $(\Omega$ ). Secara sederhana digambarkan:

$$
\mathrm{Xi}+(\theta)--------------\rightarrow X i(\theta)
$$

Bagi umat muslim ukuran yang menjadi pedoman bukanlah nilai Xi, akan tetapi nilai Xi $(\theta)$, dimana nilai material menjadi dasar penilaian yang selalu diikuti oleh non-material yaitu nilai $(\theta)$. Dalam ilmu ekonomi riil, terutama kaidah ilmu yang mempelajari tentang kegiatan ekonomi manusia dalam ruang lingkup komunitas yang terbatas, diyakini pasti ada sesuatu yang mendodong manusia untuk melakukan atau tidak melakukan sesuatu.

\section{METODOLOGI PENELITIAN \\ Desain Penelitian}

Penelitian ini penelitian yang bersifat deskriptif, eksploratif dan implementatif, didesain dengan metode kualitatif dan kuantitatif, serta menggunakan data primer dan sekunder. Data primer berupa kuesioner, observasi lapangan, interview para pelaku dan survey responden. Sedangkan data sekunder didapatkan dari data yang sudah dipublikasikan dan telah menjadi domain untuk masyarakat umum. Jenis variabel bersifat explanatory research dengan beberapa bagian penjelasan yang bersifat deskriptif qualitatif. Beberapa bagian lainnya menggunakan perhitungan kuantitatif dan bersifat implementatif dengan analisis dan hipotesis secara empiris dilapangan.

Pendekatan alat analisis atau metode yang digunakan secara kualitatif dan kuantitatif dengan alat ukur skala Likert (5). Prinsip dan cara penilaiannya dengan adopsi model kuesioner yang umum, kemudian disesuaikan dengan tingkat prioritas atau kepentingan dalam implementasi di institusi yaitu nasabah penabung Bank Pembiayaan Rakyat Syariah (BPRS)

Model pengukuran atas satu variabel pada penganut sistem liberalisme dan kapitalisme yang masih merupakan mainstream pada saat ini, kemudian dirancang dan dikolaborasikan dengan konsep dimensi immaterialitas berupa moralitas, etika dan nilai nilai sosial denngan pendekatan berdasarkan perspektif dan aqidah Islam, yaitu pendekatan metodologi Tawhidy String Relation (TSR). 


\section{Metode Pengumpulan Data}

Penelitian ini menggunakan data primer dan sekunder melalui studi kepustakaan, interviewed para pelaku, observasi, kuesioner dan data sekunder indikator BPRS, Bengkulu. Data sekunder didapatkan dari berbagai sumber studi ilmiah dalam bentuk jurnal atau penelitian ilmiah yang telah dipublikasikan. Data sekunder yang dimaksudkan adalah penelitian yang menggunakan data yang sudah diolah masing masing pemilik sumber data.

Data yang utama didapatkan dari berbagai sumber tersebut diatas difokuskan pada data variabel utama/inti yang ada dalam penelitian. Dengan memperhatikan kompleksitas data yang diperlukan, maka media penyimpanan sumber data bisa berupa hard copy atau soft copy.

\section{Prosedur Pengumpulan Data}

Prosedur pengumpulan data pada penelitian ini meliputi dua tahapan, yang disesuaikan dengan jadwal penelitian dan tingkat kebutuhan :

1. Tahap pertama dilakukan studi kepustakaan dengan mengumpulkan materi data dan data pendukung yang sudah dipublikasikan, dalam buku, jurnal, penelitian ilmiah, thesis, disertasi yang mempunyai kaitan dengan penelitian.

2. Tahap kedua dengan melakukan observasi lapangan untuk mengidentifikasi dan analisi objek yang biasa atau secara umum digunakan untuk melakukan penilaian atas persepsi para penabung di BPRS.

3. Melakukan interview terstruktur pada beberapa masyarakat, alim ulama dan tokoh setempat, untuk menentukan beberapa ukuran kesadaran masyarakat menabung di BPRS.

4. Melakukan pemeriksaan data sekunder yang ada di Badan Pusat Statistik (BPS) atau Bank Indonesia (BI) untuk mendapatkan realisasi data pada spesifikasi periode yang tercantum dalam batasan penelitian.

5. Melakukkan penyebaran kuesioner dan atau FGD yang relevan untuk mengukur dan menguji tingkat kebajikan $(\theta)$ yang melekat pada tiap variabel sesuai dengan kaidah TSR.

\section{Cara Pengolahan Data}

berikut:

Cara pengolahan data pada penelitian meliputi beberapa tahapan atau proses eksploratif, sebagai

\section{Data observasi}

Data observasi adalah data yang dikumpulkan dari lapangan dengan berinteraksi langsung kepada calon responden secara personal, yang merupakan penabung di BPRS. Kegiatan kesehariannya, kehidupannya dan pandangannya tentang menabung atau menitipkan pengelolaan uang lebih (surplus) yang dimilikinya.

\section{Data interviewed terstruktur dan FGD}

Data interviewed terstruktur adalah data yang dikumpulkan dari calon responden, untuk mendapatkan gambaran alasan utama mereka menabung di BPRS. Sedangkan focus group discussion (FGD) adalah diskusi ringan beberapa pegawai BPRS dan nasabah (penabung). Kedua data ini dimaksudkan untuk mendapatkan gambaran umum terhadap calon responden, atas deskripsi kualitas atas komponen nilai nilai yang melekat pada pilihan menabung di BPRS.

\section{Data Kuesioner}

Data quesioner diperlukan untuk mengetahui, dimensi ukuran atas variabel margin penabung di BPRS yaitu $X(\theta)$, dipandang dari segi nilai intangible atau nilai immaterial atau nilai ukhrowi. Nilai $(\theta)$ pada segi pemahaman universal adalah moralitas, etika dan social value akan diukur dalam persepsi para penabung atau masyarakat.

\section{Definisi Operasional Variabel dan Ukuran Variabel}

Berdasarkan survey pendahuluan, berupa observasi lapangan, interviewed calaon responden dan FGD terbatas didapatkan suatu kerangka penetapan atas, difinisi operasional variabel sebagai berikut:

1. Kesesuaian Aqidah $\left(\theta_{1}\right)$, adalah data primer, persepsi para penabung di BPRS atas nilai bagi hasil tabungan mereka. Data ini diukur dengan skala Likert (5) dengan nilai maksimum 5, nilai minimum 1 dan nilai tengah 3 .

2. Kemanfaatan Sosial $\left(\theta_{2}\right)$, adalah data primer, persepsi para penabung di BPRS atas nilai bagi hasil tabungan mereka. Data ini diukur dengan skala Likert (5) dengan nilai maksimum 5, nilai minimum 1 dan nilai tengah 3 .

3. Ketersediaan Pilihan atau Fasilitas $\left(\theta_{3}\right)$, adalah data primer, persepsi para penabung di BPRS atas nilai bagi hasil tabungan mereka. Data ini diukur dengan skala Likert (5) dengan nilai maksimum 5, nilai minimum 1 dan nilai tengah 3. 
4. Pelayanan dan Personalitas Petugas $\left(\theta_{4}\right)$, adalah data primer, persepsi para penabung di BPRS atas nilai bagi hasil tabungan mereka. Data ini diukur dengan skala Likert (5) dengan nilai maksimum 5, nilai minimum 1 dan nilai tengah 3.

\section{HASIL PENELITIAN DAN PEMBAHASAN}

Di dalam bab ini akan diuraikan hal-hal yang berkaitan dengan hasilpengolahan data dan pembahasan dari hasil pengolahan data tersebut. Adapunpembahasan yang dimaksud meliputi: deskripsi hasil penelitian dan hasil kuesioner responden dan diimplementasikan dalam model yang telah dikembangkan dalam metodologi TSR. Data statistik individual juga diberikan untuk memberikan gambaran umumnya.

\section{Gambaran Sampel}

Penelitian ini menggunakan metode peyebaran quisioner kepada sebagian dari para nasabah penabung PT BPRS Muamalat Hakat, yang dijadikan sebagai obyek dalam penelitian ini adalah penabung di PT BPRS Muamalat Harkat berjumlah 147 orang, nasabah penabung yang dijadikan sampel telah mengisi pertanyaan-pertanyaan dalam bentuk qesioner yang berisi tetang unsur-unsur intangibel value atas bagi hasil tabungan, pertayan-pertayaan yang berkaita dengan intangibel value atas bgi hasil tabungan adalah sebagai berikut :

Tabel 1 : Hasil $\theta_{1}$ "Kesesuaian Aqidah"

\begin{tabular}{|c|c|c|c|c|c|c|c|c|c|c|c|c|c|}
\hline \multicolumn{14}{|c|}{ I. Identifikasi kualitas nilai margin berdasarkan "Kesesuaian Aqidah" } \\
\hline No & Uraian & $\begin{array}{l}\text { No. } \\
1\end{array}$ & $\begin{array}{c}\text { No. } \\
2 \\
\end{array}$ & $\begin{array}{l}\text { No. } \\
3 \\
\end{array}$ & \begin{tabular}{|c|} 
No. \\
4
\end{tabular} & $\begin{array}{l}\text { No. } \\
5\end{array}$ & \begin{tabular}{|l|} 
No. \\
6 \\
\end{tabular} & $\begin{array}{l}\text { No. } \\
7\end{array}$ & s/d & $\begin{array}{l}\text { No. } \\
145\end{array}$ & $\begin{array}{l}\text { No. } \\
146 \\
\end{array}$ & $\begin{array}{l}\text { No. } \\
147\end{array}$ & Rerata \\
\hline 1. & $\begin{array}{l}\text { Nilai margin atas tabungan dalam system perbankan konvensional } \\
\text { (Bank BNI sebagai contoh) berdasarkan aqidah agama islam } \\
\text { mengandung unsur riba yang berarti "haram" }\end{array}$ & 4 & 5 & 4 & 4 & 4 & 3 & 4 & ..."' & 4 & 3 & 5 & 3,93 \\
\hline 2. & $\begin{array}{l}\text { Nilai margin atas tabungan dalam perbankan syariah (BPRS) } \\
\text { adalah system bagi hasil dan berdasarkan aqidah agama di } \\
\text { perbolehkan atau halal. }\end{array}$ & 4 & 5 & 4 & 5 & 3 & 4 & 5 & ...".' & 4 & 3 & 5 & 4,10 \\
\hline 3. & $\begin{array}{l}\text { Saya memilh yang halal walaupun nilai kuantitasnya kecil (Rp.1 } \\
\text { juta misalnya) dari pada yang bernilai kuantitas besar (Rp. } 5 \text { Juta) } \\
\text { tetanisecara anidah statısnva haram. }\end{array}$ & 5 & 5 & 4 & 4 & 5 & 5 & 5 & .....". & 4 & 3 & 5 & 4,26 \\
\hline 4. & $\begin{array}{l}\text { Identitas kualifikasi halal dan haram sangat penting bagi } \\
\text { kehidupan saya dalam mengelola kegiatan ekonomi (mengelola } \\
\text { uano tabunoan). }\end{array}$ & 3 & 5 & 3 & 5 & 4 & 5 & 5 & ....'.' & 4 & 5 & 5 & 4,17 \\
\hline 5. & $\begin{array}{l}\text { Margin bagi hasil atas tabungan di BPRS (halal) memberi nilai } \\
\text { ketenangan dalam keterkaitan dengan kegiatan ekonomi lainnya. }\end{array}$ & 5 & 4 & 3 & 4 & 3 & 3 & 3 & "..."' & 4 & 4 & 5 & 3,84 \\
\hline 6. & $\begin{array}{l}\text { Kualitas atas pendapatan (margin tabungan) yang halal } \\
\text { mempunyai value atau nilai yang tidak tergantikan oleh besamya } \\
\text { kuantitas vana haram. }\end{array}$ & 4 & 4 & 4 & 4 & 5 & 3 & 5 & ...." & 4 & 2 & & 3,99 \\
\hline & & 4,17 & 4,67 & 3,67 & 4,33 & 4,00 & 3,83 & 4,50 & $\ldots .$. & 4,00 & 3,33 & 5,00 & 4,05 \\
\hline
\end{tabular}


Tabel 2 : Hasil $\theta_{2}$ "Kemanfaatan sosial”

\begin{tabular}{|c|c|c|c|c|c|c|c|c|c|c|c|c|c|}
\hline & II. Identifikasi kualitas nilai margin berdasarkan "kemanf & & & & & & & & & & & & \\
\hline No & Uraian & $\begin{array}{l}\text { No. } \\
1\end{array}$ & $\begin{array}{c}\text { No. } \\
2 \\
\end{array}$ & $\begin{array}{l}\text { No. } \\
3\end{array}$ & $\begin{array}{l}\text { No. } \\
4\end{array}$ & $\begin{array}{c}\text { No. } \\
5 \\
\end{array}$ & $\begin{array}{c}\text { No. } \\
6 \\
\end{array}$ & $\begin{array}{c}\text { No. } \\
7 \\
\end{array}$ & s/d & $\begin{array}{l}\text { No. } \\
145\end{array}$ & $\begin{array}{l}\text { No. } \\
146\end{array}$ & $\begin{array}{l}\text { No. } \\
147\end{array}$ & Rerata \\
\hline 1. & $\begin{array}{l}\text { Bila ada uang lebih dalam keluarga akan lebih baik dimamfaatkan } \\
\text { oleh masyarakat yang memerlukan dari pada disimpan sendin } \\
\text { atau dianoqurkan saia. }\end{array}$ & 4 & 4 & 3 & 3 & 5 & 3 & 5 & n.mon & 4 & 3 & 3 & 3,70 \\
\hline 2. & $\begin{array}{l}\text { Menyimpan uang di BPRS adalah satu bentuk ibadah (membantu } \\
\text { bagi mereka yang sangat memerlukan untuk modal usaha atau } \\
\text { kenerluan lain vano sanoat mendesak. }\end{array}$ & 5 & 4 & 3 & 4 & 4 & 4 & 5 & ...... & 4 & 3 & 4 & 3,92 \\
\hline 3. & $\begin{array}{l}\text { Menabung di BPRS dengan system sesuai syariah mempunyai } \\
\text { tingkat kemaslahatan lebih baik dari pada menabung di bank } \\
\text { konvensional. }\end{array}$ & 4 & 3 & 4 & 3 & 3 & 3 & 5 & ....n." & 3 & 3 & 4 & 3,83 \\
\hline 4. & $\begin{array}{l}\text { Para kreditur dalam hal ini pengusaha mikro atau masyarakat kecil } \\
\text { lebih suka pinjam di BPRS dari pada di bank konvensional }\end{array}$ & 3 & 3 & 3 & 3 & 4 & 3 & 3 & ...... & 3 & 3 & 3 & 3,35 \\
\hline 5. & $\begin{array}{l}\text { Nilai pinjaman di BPRS umumnya lebih kecil nilainya dari pada di } \\
\text { bank konvensional sehingga untuk jumlah nilai tertentu, tingkat } \\
\text { kemaslahatan tabungan di BPRS lebih besar daripada di bank } \\
\text { knnvensional. }\end{array}$ & 3 & 4 & 4 & 3 & 3 & 3 & 4 & ...m. & 3 & 4 & 4 & 3,68 \\
\hline 6. & $\begin{array}{l}\text { Secara umum BPRS lebih disukai oleh masyarakat daripada bank } \\
\text { konvensional. }\end{array}$ & 4 & 4 & 5 & 4 & 5 & 4 & 4 & ..." & 4 & 3 & 3 & 3,73 \\
\hline & & 3,83 & 3,67 & 3,67 & 3,33 & 4,00 & 3,33 & 4,33 & $\ldots .$. & 3,50 & 3,17 & 3,50 & 3,70 \\
\hline
\end{tabular}

Tabel 3 : Hasil $\theta_{3}$ "Ketersediaan pilihan dan fasilitas".

\begin{tabular}{|c|c|c|c|c|c|c|c|c|c|c|c|c|c|}
\hline \multicolumn{14}{|c|}{ III. Identifikasi kualitas nilai margin berdasarkan "ketersediaan pilihan dan fasilitas" } \\
\hline No & Uraian & No. & No. & No. & No. & No. & No. & No. & $s / d$ & No. & No. & No. & Rerata \\
\hline & & 1 & 2 & 3 & 4 & 5 & 6 & 7 & & 145 & 146 & 147 & \\
\hline 1. & $\begin{array}{l}\text { Dilokasi tempat para penabung berada mempunyai alternatif } \\
\text { (ada bank lain) dalam menyimpan uang. }\end{array}$ & 3 & 4 & 5 & 3 & 5 & 3 & 5 & $\ldots$ & 4 & 3 & 4 & 3,95 \\
\hline 2. & $\begin{array}{l}\text { Kegiatan menabung dan menarik uang di BPRS sudah } \\
\text { mendapatkan layanan yang levelnya sebanding dengan bank } \\
\text { konvensional. }\end{array}$ & 5 & 4 & 4 & 3 & 5 & 3 & 5 & $\ldots . .$. & 4 & 4 & 5 & 3,89 \\
\hline 3. & $\begin{array}{l}\text { Dalam kegiatan menabung dan menarik uang di BPRS ada } \\
\text { semacam nilai sosial dan atau spiritual. }\end{array}$ & 4 & 3 & 4 & 4 & 3 & 4 & 3 & ......... & 4 & 3 & 4 & 3,66 \\
\hline 4. & $\begin{array}{l}\text { Fasilitas pelayanan BPRS sudah cukup bagus dan sebanding } \\
\text { dengan pelayanan di bank konvensional. }\end{array}$ & 4 & 3 & 4 & 4 & 4 & 4 & 5 & ....... & 4 & 3 & 4 & 3,90 \\
\hline 5. & $\begin{array}{l}\text { Jaminan resiko atas tabungan di BPRS sudah sama atau } \\
\text { selevel dengan di bank konvensional. }\end{array}$ & 4 & 4 & 4 & 4 & 4 & 5 & 5 & $\ldots . .$. & 3 & 3 & 4 & 4,04 \\
\hline \multirow[t]{2}{*}{6.} & $\begin{array}{l}\text { Usaha untuk bertransaksi di BPRS sudah sama atau selevel } \\
\text { dengan di bank konvensional. }\end{array}$ & 4 & 4 & 5 & 4 & 4 & 5 & 4 & ...... & 3 & 3 & 4 & 3,91 \\
\hline & & 4,00 & 3,67 & 4,33 & 3,67 & 4,17 & 4,00 & 4,50 & ...... & 3,67 & 3,17 & 4,17 & 3,90 \\
\hline
\end{tabular}


Tabel 4 : Hasil $\theta_{4}$ "Pelayanan dan personalitas petugas".

\begin{tabular}{|c|c|c|c|c|c|c|c|c|c|c|c|c|c|}
\hline \multicolumn{14}{|c|}{ IV. Identifikasi kualitas margin berdasarkan "pelayanan dan personality petugas" } \\
\hline No & Uraian & $\begin{array}{c}\text { No. } \\
1\end{array}$ & $\begin{array}{c}\text { No. } \\
2\end{array}$ & $\begin{array}{c}\text { No. } \\
3\end{array}$ & $\begin{array}{c}\text { No. } \\
4\end{array}$ & $\begin{array}{l}\text { No. } \\
5\end{array}$ & $\begin{array}{c}\text { No. } \\
6\end{array}$ & $\begin{array}{c}\text { No. } \\
7\end{array}$ & s/d & $\begin{array}{l}\text { No. } \\
145\end{array}$ & $\begin{array}{l}\text { No. } \\
146\end{array}$ & $\begin{array}{l}\text { No. } \\
147\end{array}$ & Rerata \\
\hline 1. & $\begin{array}{l}\text { Pelayanan transaksi keuangan oleh petugas di BPRS sudah sama } \\
\text { dan selevel dengan pelayanan petugas di bank konvensional. }\end{array}$ & 4 & 4 & 4 & 4 & 5 & 4 & 4 & ....... & 4 & 3 & 3 & 3,90 \\
\hline 2. & $\begin{array}{l}\text { Para petugas BPRS lebih mengetahui (secara personality lebih } \\
\text { dekat) daripada bank konvensional. }\end{array}$ & 5 & 4 & 4 & 4 & 3 & 5 & 5 & ...... & 4 & 3 & 5 & 3,99 \\
\hline 3. & $\begin{array}{l}\text { Dalam proses pembukaan dan penutupan tabungan di BPRS lebih } \\
\text { mudah daripada bank konvensional. }\end{array}$ & 4 & 5 & 5 & 5 & 3 & 4 & 4 & ........ & 4 & 3 & 5 & 4,32 \\
\hline 4 & $\begin{array}{l}\text { Secara hubungan/pribadi apakah para penabung merasa lebih } \\
\text { dekat atau lebih merasa nyaman berinteraksi/berkomunikasi } \\
\text { dengan petugas bank syariah daripada bank konvensional }\end{array}$ & 5 & 4 & 4 & 4 & 4 & 5 & 4 & ....... & 4 & 3 & 5 & 4,08 \\
\hline 5 & $\begin{array}{l}\text { Para pegawai bank syariah lebih peduli/lebih memperhatikan para } \\
\text { penabung jika dibandingkan dengan para pegawai bank } \\
\text { konvensional. }\end{array}$ & 5 & 4 & 4 & 4 & 3 & 5 & 5 & ......' & 4 & 3 & 4 & 4,07 \\
\hline 6 & $\begin{array}{l}\text { Para pegawai bank syariah sering melibatkan penabung dalam } \\
\text { kegiatan keluarga atau pribadi dibandingkan dengan para pegawai } \\
\text { bank konvensional. }\end{array}$ & 5 & 4 & 4 & 4 & 3 & 5 & 3 & ....' & 4 & 3 & 5 & 3,60 \\
\hline & & 4,67 & 4,17 & 4,17 & 4,17 & 3,50 & $4,67 \mid$ & 4,17 & $\ldots$. & 4,00 & 3,00 & 4,50 & 3,99 \\
\hline
\end{tabular}

Deskripsi Statistik Hasil Penelitian

Berdasarkan pengolahan data diperoleh nilai rata-rata intangibel value dari masing-masing faktor. Hal tersebut dapat dilihat pada tabel berikut :

\begin{tabular}{|lcccc|}
\hline & DATA_1_ & DATA_2_ & DATA_3_ & DATA_4 \\
Mean & 4.047846 & 3.701814 & 3.895692 & 3.993197 \\
Median & 4.000000 & 3.666667 & 4.000000 & 4.000000 \\
Maximum & 5.000000 & 4.833333 & 4.833333 & 5.000000 \\
Minimum & 3.000000 & 3.166667 & 2.833333 & 3.000000 \\
Std. Dev. & 0.316446 & 0.311641 & 0.314666 & 0.397326 \\
Skewness & 0.349393 & 0.574702 & -0.395061 & 0.103285 \\
Kurtosis & 4.182722 & 3.393525 & 4.700263 & 2.790773 \\
& & & & \\
Jarque-Bera & 11.55868 & 9.040442 & 21.53051 & 0.529489 \\
Probability & 0.003091 & 0.010887 & 0.000021 & 0.767402 \\
Sum & & & & 587.0000 \\
Sum Sq. Dev. & 14.62015 & 14.17952 & 14.45616 & 23.04875 \\
Observations & 147 & 147 & & \\
\hline
\end{tabular}

Tabel 4.6 : Data Statistik Hasil $\theta_{1}, \theta_{2}, \theta_{3}, \theta_{4}$

Berdasarkan tabel di atas dapat dilihat elemen itangible value yang berkaitan dengan kesesuain aqidah mempunyai nilai theta yang tinggi degan rata-rata nilai Theta sebesar 4,05, elemen yang lain yang berkaitan dengan kemanfaatan sosial mempuyai nilai theta rata-rata sebesar 3,70, elemen ketersediaan pilihan dan fasilitas mempuyai nilai theta rata-rata sebesar 3,90 sedangkan elemen yang terakhr mengenai pelayanan dan personality petugas mempunyai nilai rata-rata sebesar 3,99 . 


\section{Pembahasan}

\section{Faktor Kesesuaian aqidah}

Dari hasil pengolahan data dalam penelitian ini menunjukkan bahwa Itangibel value atas bagi hasil tabungan berupa faktor kesesuaian aqidah mempuyai nilai yang cukup tingi yaiu 4,04 dimana faktor kesesuaian aqidah ini mempunyai peran atau pengaruh yang kuat kepada seorang untuk menabung di PT BPRS Muamalat Harkat, dalam hal ini seseorang akan memperhatikan hal-hal yang berkaitan dengan aqidah yaitu Nilai margin atas tabungan dalam system perbankan konvensional berdasarkan aqidah agama islam mengandung unsur riba yang berarti "haram", sementara nilai bagi hasil atas tabungan dalam perbankan syariah (BPRS) adalah system bagi hasil dan berdasarkan aqidah agama di perbolehkan atau halal, walaupun nilai kuantitasnya kecil dari pada yang bernilai kuantitas besar tetapi secara aqidah statusnya haram.Identitas kualifikasi halal dan haram sangat penting bagi kehidupan seseorang dalam mengelola kegiatan ekonomi (mengelola uang tabungan). Bagi hasil atas tabungan di BPRS sifatya halal dan memberi nilai ketenangan dalam keterkaitan dengan kegiatan ekonomi lainnya.Kualitas atas pendapatan (bagi hasil tabungan) yang halal mempunyai value atau nilai yang tidak tergantikan oleh besarnya kuantitas yang haram.

\section{Kemanfaatan sosial}

Dari hasil pengolahan data dalam penelitian ini menunjukkan bahwa Itangibel value atas bagi hasil tabungan berupa elemen Kemanfaatan sosial mempuyai nilai theta yang cukup tingi yaitu 3,70 dimana elemen Kemanfaatan sosial ini mempunyai peran atau pengaruh yang cukup kuat kepada seorang untuk menabung di PT BPRS Muamalat Harkat, dalam hal ini seseorang akan memperhatikan hal-hal yang berkaitan dengan kemanfaatan sosial yaitu Bila ada uang lebih dalam keluarga akan lebih baik dimanfaatkan oleh masyarakat yang memerlukan dari pada disimpan sendiri atau dianggurkan saja. Wadah atau tempat yag aman yaitu degan cara menabung di bank syariah. Menyimpan uang di BPRS adalah satu bentuk ibadah (membantu bagi mereka yang sangat memerlukan untuk modal usaha atau keperluan lain yang sangat mendesak), menabung di BPRS dengan system sesuai syariah mempunyai tingkat kemaslahatan lebih baik dari pada menabung di bank konvensional.

\section{Ketersediaan pilihan dan fasilitas}

Dari hasil pengolahan data dalam penelitian ini menunjukkan bahwa Itangibel value atas bagi hasil tabungan berupa elemen Ketersediaan pilihan da fasilitas mempuyai nilai theta yang cukup tingi yaiu 3,90 dimana elemen Ketersediaan pilihan dan fasilitas mempunyai peran atau pengaruh yang cukup kuat kepada seorang untuk menabung di PT BPRS Muamalat Harkat dalam hal ini seseorang akan memperhatikan hal-hal yang berkaitan dengan ketersediaan dan fasilitas yaitu dilokasi tempat para penabung yaitu di BPRS Muamalat Harkat Bengkulu merupakan suatu alternatif karena di lokasi BPRS juga terdapat beberapa kantor unit bank konvesioal, namun kegiatan menabung dan menarik uang di BPRS sudah mendapatkan layanan yang levelnya sebanding dengan bank konvensional, dari sisi Fasilitas pelayanan BPRS sudah cukup bagus dan sebanding dengan pelayanan di bank konvensional.Jaminan resiko atas tabungan di BPRS sudah sama atau selevel dengan di bank konvensional.

\section{Pelayanan dan Personalitypetugas}

Dari hasil pengolahan data dalam penelitian ini menunjukkan bahwa Itangibel value atas bagi hasil tabungan berupa elemen Pelayanan dan personality petugas mempuyai nilai yang cukup tinggi yaiu 3,99 dimana elemen Pelayanan dan personality petugas mempunyai peran atau pengaruh yang cukup kuat kepada seorang untuk menabung di PT BPRS Mumalat Harkat, dalam hal ini seseorang akan memperhatikan hal-hal yang berkaitan dengan Pelayanan dan persoality petugas yaitu dari isi Pelayanan transaksi keuangan oleh petugas di BPRS sudah sama dan selevel dengan pelayanan petugas di bank konvensional. dalam hal kedekatan personal Para petugas BPRS lebih mengetahui (secara personality lebih dekat) daripada bank konvensional, Sehingga secara hubungan/pribadi para penabung merasa lebih dekat atau lebih merasa nyaman berinteraksi/berkomunikasi dengan petugas bank syariah daripada bank konvensional, Para pegawai bank syariah lebih peduli/lebih memperhatikan para penabung jika dibandingkan dengan para pegawai bank konvensional.Para pegawai bank syariah sering melibatkan penabung dalam kegiatan keluarga atau pribadi dibandingkan dengan para pegawai bank konvensional. 


\section{KESIMPULAN}

Dari hasil proses analisis data dan pembahasan di atas diambil kesimpulan sebagai yaitu Identifikasi dan Analisis Intangible Value atas Bagi Hasil Tabungan di PT Bank Pembiayaan Rakyat Syariah (BPRS) Muamalat Harkat Bengkulu pada elemen kesesuaian aqidah, kemanfaatan sosial, ketersediaan pilihan dan fasilitas, serta pelayanan dan personalitas petugasmempunyai pengaruh yang signifikan terhadap minat para penabung di BPRS, dengan nilai tertinggi adalah elemen Kesesuan akidah dengan dengn nilai 4,04

\section{SARAN}

1. Berdasarkan Identifikasi dan Analisis Intangible Value atas Bagi Hasil Tabungan di PT Bank Pembiayaan Rakyat Syariah (BPRS) Muamalat Harkat Bengkulu pada elemen "kesesuaian aqidah" mempunyai pengaruh yang signifikan terhadap minat para penabung di BPRS dengan nilai paling tinggi. Ini merupakan modal yang cukup bagus untuk semua pihak baik itu pihak Otoritas Jasa Keuangan, Pihak Managemen Bank Pembiayaan Rakyat Syariah (BPRS) Muamalat Harkat, pihak MUI (Majelis Ulama Idonesia)untuk lebih meningkatkan perannyamasing-masing dalam hal mensosialisasikan tentang Bank Syariah, sehingga diharapkan kedepan semakin banyak lagi masyarakat yang tertarik untuk membuka rekening tabungan di PT BPRS Muamalat Harkat, sehingg market share Perbankan syariah bisa lebih tinggi dibandingkan dengan bank konvensional.

2. Identifikasi dan Analisis Intangible Value atas Bagi Hasil Tabungan di PT Bank Pembiayaan Rakyat Syariah (BPRS) Muamalat Harkat Bengkulu pada elemen "kemanfaatan sosial" mempunyai pengaruh yang signifikan terhadap minat para penabung di BPRS dengan nilai yang paling rendah maka disarankan kepada manajemen /pengurus PT Bank Pembiayaan Rakyat Syariah (BPRS) Muamalat Harkat Bengkulu untuk lebih sering malakukan kegiatan-kegiatan sosial yang tujuannya untuk memberikan edukasi sehingga masyrakat sekitar lebih memahami tentang kemanfaatan sosial

3. Perlu dilakukan penelitian lebih lanjut terkait dengan Intangible value atas bagi hasil tabungan dengan objek penelitian yang lebih luas, baik berupa nasabah Bank Pembiayaan Rakyat Syariah (BPRS) lain di luar propinsi Begkulu atau nasabah dari Bank Umum Syariah (BUS)

\section{DAFTAR PUSTAKA}

Adiwarman A. Karim, 2011, Bank Islam Analisis Fiqh dan Keuangan. Jakarta: PT Raja Grafindo Persada H. Syukri Iska, 2012 Sistem Perbankan Syariah di Indonesia. Yogyakarta : Fajar Media Press Kasmir, 2008, Manajamen Perbankan, Jakarta : PT Raja Grafindo Persada

Panji Adam, 2018, Fatwa - Fatwa Ekonomi Syariah , Jakarta : Amzah

Statistik Perbankan Syariah Indonesia tahun 2014, 2015, 2016,2017 dan 2018 yang diterbitkan oleh Otoritas Jasa Keuangan (OJK)

Undang-Undang No. 21 tahun 2008 tentang Perbanakan Syariah

Undang-Undang No. 10 tahunn 1998 tentang Perbankan 